of every tissue in the body are altered in a degree proportionate to the extent and virulence of the infection. This infection is usually very chronic, but may be of such a nature as to cause death in a few hours. In the vast proportion of cases the infection of the food-supply is secondary to delay in the large bowel, and is a stage in the sequence which I call "chronic intestinal stasis." Occasionally the infection may result from an abundant entry of organisms and their products through the mouth. This is illustrated very clearly by McCarrison's experiments and observations on the production of goitre. In chronic intestinal stasis the infection of the chyme is often accentuated by matter entering the canal from the mouth or naso-pharynx, as, for instance, in pyorrboea.

The results of infection of the chyme by organisms are: 1. The direct extension of the infection from the duodenum along the ducts of the liver, gall-bladder, and pancreas with the conditions which ensue on this infection. 2. Degenerative changes in every tissue of the body due to the systemic supply of blood which is more or less impure, since it contains a certain quantity of deleterious substances. The liver would appear to be especially exposed to harm, since the blood reaches it through the portal vein in its most impure form. Again, the cells of this organ, overstimulated by its novel function, are damaged by the infection that reaches them through the ramifications of the infected hepatic ducts as well as through the impure blood supplied by the hepatic artery. The kidneys, skin, adrenals, thyroid, pituitary gland, and spleen cease to bear their normal relationship to the food-supply, and are overworked, such excessive function acting at first as a stimulant, which later results in exhaustion. The nutrition of the component parts of these structures is also impaired, in common with every other tissue, because of the impurity of the blood supplied to them. These organs all undergo changes wbich are described as diseases. 3. A group which might be classified as the tertiary results of chyme infection. These are due to invasion by organisms consequent on the diminished vitality of the tissues, and include an immense variety of so-called diseases, none of which could arise without the antecedent existence of chyme infection. I refer to such varied conditions as rheumatoid arthritis, tubercle, Still's disease, ulcerative endocarditis, pyorrhcea, obliterative arteritis, many forms of skin disease, \&c.

These consequences can in most cases only be dealt with effectually by the sterilisation of the contents of the stomach and small intestine.-I am, Sir, yours faithfully, April 15th, 1919.

W. ARBUTHNOT LANE.

\section{DEPARTMENT OF HEALTH FOR CANADA.}

\section{To the Editor of THE LANCET.}

SIR, - On the tide of reconstruction in Canada there has just been borne into the Dominion House of Commons a Bill to create a Federal Department of Health, introduced by the Hon. N. W. Rowell, President of the Privy Council. For some years a strong and active movement has been in progress, led chiefly by the Commission of Conservation through its Public Health Committee, of which the writer is medical adviser. The Committee has made repeated representations to successive Governments and urged that it was the duty of the Federal authorities to conserve the health of the people and that the first step should be the establishment of a Department of Health. In October, 1910, a conference was convened in Ottawa of representatives of the provincial governments and Federal representatives under the chairmanship of Sir Edmund Osler, when a series of recommendations were made, and subsequently laid before the then Premier, Right Hon. Sir Wilfrid Laurier, and subsequently before the present Premier, Right Hon. Sir Robert Borden.

The important features of these recommendations were: (a) the establishment of a Federal Department of Health; (b) a national council of representatives from each of the provinces ; $(c)$ the consolidation of the work of quarantining, medical inspection of immigrants, inspection of foods and drinks and other matters at present controlled by the Federal government but operated by different departments ; their administration to be placed in the hands of a Minister of Health; $(d)$ the pollution of streams; $(e)$ the establishment of health laboratories for the preparation of sera, xc., and for the conducting of research work ; $(f)$ the securing of greater coöperation of the provinces in bealth work generally.

This action on the part of the Commission was strongly supported by the Dominion Medical Association, as well as by the several provincial organisations, and by a large body of the public press and associations interested in the welfare of the people.

As a result of war conditions and the appalling effects of the recent epidemic of influenza and doubtless stimulated by the words of the Premier of Great Britain and the subsequent action of the British Government, it is gratifying to note the proposals of the Dominion Government on this question which aims at placing health as a foundation of Government, thereby assuring to the people that the vital problems which concern a nation and upon which depend its very existence, continuity, and efficiency, are those which will hereafter receive its most serious and constant attention.

The Bill as introduced provides for the establishment of a Department of Health, with a Minister, Deputy Minister, and Advisory Council, and-

"The duties and powers of the Minister administering the Department of Health shall extend to and include all matters and questions relating to the promotion or preservation of the health and social welfare of the people of Canada over which the Parliament of Canada has jurisdiction; and, without restricting the generality of the foregoing, particularly the following matters and subjects: (a) coopperation with the provincial, territorial, and other health autborities with a view to the coorrdination of the efforts proposed or made for preserving and improving the public health (b) the conservation of child life and child welfare; $(c)$ the inspection and medical care of immigrants and seamen, and the administration of marine hospitals ; $(d)$ the supervision as regards the public health, of railways, boats, ships, and al methods of transportation; $(e)$ the supervision of Federal public buildings and offices with regard to the health of the Civil servants and other Government employees therein; $(f)$ the enforcement of any rules or regulations made by the International Joint Commission promulgated pursuant to the treaty between the United States of America and His Majesty relating to boundary waters and questions arising between the United States of America and Canada so far as the same relate to public health ; $(g)$ the administration of the statutes mentioned in the Schedule to this Act and of Acts amending the same, and also of all orders and regulations passed or made under any of the said Acts, and all the duties and powers of any Minister of the Crown under either of the said Acts or any of the said orders or regulations are hereby transferred to and conferred upon the Minister of Health ; $(h)$ the collection, publication, and distribution of information to promote good health and improved sanitation; (i) such other matters as may be referred to the Minister by the Governor in Council."

From the manner in which the question bas been already referred to in the House by those Members who spoke in the Address to the Throne the question seems to meet with general approval, and but little opposition is coming from the daily press. Of course, some is expected from those of Christian Scientist and antivaccination proclivities, whicb, however, are of but slight importance and cannot affect the issue.

I am, Sir, yours faithfully,

Chas. A. Hodgetts, M.D., D.P.H., \&c. Medical Adviser, Public Health Comm
Ottawa, March 28th, 1919.

\section{THE AFTER-CARE OF TUBERCULOUS EX-SERVICE MEN. \\ To the Editor of The LANOET.}

SiR,-The Society of Medical Officers of Health recently had under consideration the circular of the Local Government Board, dated Dec. 4th, 1918, in regard to the home visiting and after-care of discharged soldiers and sailors suffering from tuberculosis. It was decided to point out to the Board that the circular might be interpreted as making the tuberculosis officer directly responsible for measures in this connexion. In reply the Board have assured the society that the circular "was not intended to suggest in any way that the tuberculosis officer should, except as far as his clinical duties are concerned, act otherwise than under the direction of the medical officer of health." The Board add that the position of the medical officer of health in relation to the administration of sanatorium benefit is 